\title{
CIVILII ŞI ARMATA ROMANĂ. LIXAE ŞI CALONES
}

\author{
Gabriel-Iulian Stoian
}

\section{Civilians and the Roman Army. Lixae and calones}

Although the Roman army is often described as a rigid structure, following strict discipline and organization, the literary sources mention different sorts of civilians, who interfere with the military life, especially lixae and calones, oftentimes mentioned together.

Regarding the first group (lixae), this study strives to understand their function in relation to the army. Generally, lixae were an etherogeneous group, gathering all sorts of people, but chiefly merchants following the army in search for profit. The epigraphic evidence presents lixae as being attached to different Roman units and therefore it is necessary to determine their status in relation to the soldiers and whether they could be placed among army's ranks. Another issue is represented by their social status, as both the primary sources and the related scholarship presents them as free men or servants.

Regarding the second group, calones, their status is undoubtedly of servile nature. Mentioned especially in relation to the baggage train, their function seems a little more complex and varied, as they freed the soldier of many of his daily duties. Excepting their logistical function, analyzing the testimonies regarding calones will also reveal a military role: in exceptional cases, they were used by the Roman commanders as the last reserve of the army or as maneuver troops. The size of the group is also marked by incertitude, but the most convenient figure seems to be a ratio of one calo for every four soldiers.

Cuvinte cheie: armată romană, civili, sclavi, lixae, calones.

Key words: Roman Army, civilians, slaves, lixae, calones.

În ciuda volumului mare de studii şi articole dedicate armatei romane, există totuşi o latură puțin cercetată a acesteia: cea a sclavilor militarilor şi a civililor care însoțeau armata în campanii.

În domeniul organizării logistice, romanii operau o distincție clară între bagajele armatei în ansamblu (impedimenta) sau „trenul legionar"1 şi bagajele personale ale soldaților (sarcinae). Tradiția îi atribuie lui Marius înființarea acestui $\operatorname{tren}^{2}$ în a cărui componență se pot surprinde, încă din timpul lui Caesar, diverse categorii de civili, îndeosebi lixae şi calones, deşi de multe ori în sursele narative toate aceste categorii sunt grupate sub denumiri care desemnează întreaga colectivitate: mancipia $^{3}$, servitia ${ }^{4}$, pueri $^{5}$, accensi $^{6}$, agasones $^{7}$. De altfel, Flavius Iosephus afirmă că în momentul în care o legiune era în marş era urmată de bagajele sale şi apoi de sclavi ${ }^{8}$.

\footnotetext{
${ }^{1}$ Termen utilizat cu precădere de reprezentanții şcolii anglo-americane.

${ }^{2}$ Frontinus, Str., 4, 17.

${ }^{3}$ Caesar, B. Civ., 3, 6; Hirtius, B. Afr., 47, 3; Tacitus, Ann. 15, 15.

${ }^{4}$ Hirtius, B. Afr., 85, 2; Velleius Paterculus, Hist. Rom., 2, 82; SHA, Hadr., $13,7$.

${ }^{5}$ Hirtius, B. Afr., 85, 2.

${ }^{6}$ Titus Livius, Ab Urbe Cond., 8, 8-10.

${ }^{7}$ Frontinus, Str., 2, 4, 6.

${ }^{8}$ Flavius Iosephus, B. Iud., 5, 49.
} 


\section{Lixae}

În ceea ce priveşte primul grup (lixae), încă din perioada antică s-a încercat explicarea ocupației acestora pe baza etimologiei termenului care îi desemnează. Astfel, Nonius afirmă că în vechime substantivul ,apă” era desemnat prin termenul de lixa ${ }^{9}$, ipoteză confirmată şi de Isidor din Sevilla care îl prezintă ca fiind sinonim cu $a q u a^{10}$ şi în consecință lixae ar fi fost cei ce aduceau apă soldaților. Această explicație etimologică este grevată însă de o doză ridicată de incertitudine, întrucât în vremea în care cei doi îşi redactează opera este posibil ca termenul să fi fost perceput distorsionat. Mai mult, în sursele narative mai vechi nu apar indicii care să sprijine această conjectură. Procedând într-o manieră similară, Festus oferă două explicații diferite: Unii spun că se numesc aşa de la Lichas, deoarece acesta l-a urmat pe Hercule, alţii de la ,, ligurrire","1. În mod evident, ambele interpretări converg spre ideea de a urma cuiva, idee preluată şi de unii cercetători moderni, aceştia considerând că termenul ar deriva de la participiul lui linquo: licta, lixae primind probabil acest apelativ întrucât adunau bunurile ce rămâneau în urma unei bătălii ${ }^{12}$.

\section{I.1. Funcții}

Mult mai plauzibil este ca acest termen să fi desemnat generic persoane cu ocupaţii diverse, care urmau armata, vânzând soldaților diverse mărfuri, cu predilecție diverse alimente. Acest sens, de comerciant, apare la Ammianus Marcellinus ${ }^{13}$, dar şi la Hirtius - lixae mercatoresque, qui plaustris merces portabant ${ }^{14}$. În plus, Ammianus Marcellinus realizează o corelație între lixae şi prepararea mâncării. Conform acestuia, Ampelius, în calitate de praefectus Urbi între 371-372 p. Chr., dorind să îndrepte moravurile, a ordonat ca nici un local în care se servea vin să nu se deschidă înainte de ora patru şi nici o lixa să nu ofere mâncare gătită ${ }^{15}$. În acelaşi registru ar putea fi interpretată relatarea lui Sallustius care aminteşte că Mettelus, după ce a sosit în Numidia pentru a lupta cu Iugurtha, a îndepărtat indolența printr-un ordin, potrivit căruia nimeni nu mai avea voie să vândă pâine sau altă mâncare gătită în interiorul taberei, iar lixaelor li s-a interzis să urmeze armata ${ }^{16}$. Şi Festus îi defineşte pe lixae ca fiind persoane care urmează armata în căutarea profitului - quaestus gratia ${ }^{17}$. De asemenea, când în anul 16 p. Chr. uzurpatorul Catualda îl răstoarnă pe regele marcoman Maroboduus găseşte în palatul acestuia un număr important de lixae şi negotiatores din provinciile romane ajunşi acolo grație privilegiilor comerciale, din dorința de a obține un profit ridicat ${ }^{18}$.

Probabil, bunurile pe care lixae le comercializau proveneau şi din jaf. Astfel, Titus Livius referindu-se la campania din Liguria menţionează că zona era săracă, obligându-i pe soldați la o viață simplă şi oferindu-le o pradă redusă. În consecință, nici un lixa nu îi însoțea ${ }^{19}$. Într-un alt pasaj al operei lui Sallustius, pentru a se ilustra dezordinea desăvârşită din armata lui Postumius Albinus din Numidia în 109 a.Chr., se afirma că lixae şi soldații au mărşăluit împreună zi şi noapte şi în incursiunile lor au devastat ținutul, au atacat fermele şi s-au întrecut

\footnotetext{
${ }^{9}$ Nonius Marcellus, De compediosa doctrina ad filium, 48, 17.

${ }^{10}$ Isidor din Sevilla, Etym., s.v. lixones.

${ }^{11}$ Festus, De verborum segnificatu, 4, 116.

12 Pentru întrega problematică vezi Cagnat 1904, 1279; Grosse 1926, 929-930; Barbieri 1964, 1426-1427; von Petrikovitz 1980, 1027-1035; Neumann 1979, 699; Feig Vishnia 2002, 265-272; Thorburn 2003, 47-61; Wierschowski 1984, 112-121; Schlippschuh 1987, 20-21; Kissel 1995, 50-53; Roth 1999, 230-231, 270-271.

${ }^{13}$ Ammianus Marcellinus, 28, 4, 1 .

${ }^{14}$ Hirtius, B. Afr., 75.

${ }^{15}$ Ammianus Marcellinus, 28, 4, 2.

${ }^{16}$ Sallustius, Iug., 45, 2.

${ }^{17}$ Festus, Etym. s.v. lixa.

${ }^{18}$ Tacitus, Ann., 2, 26.

${ }^{19}$ Titus Livius, Ab Urbe Cond., 39, 1,7.
} 
în o obține prăzi extraordinare constând în vite şi sclavi, pe care le-au schimbat pentru vin de import şi alte obiecte de $\operatorname{lux}^{20}$.

Delimitarea lor în raport cu negotiatores sau mercatores pare la o analiză superficială redundantă din moment ce toți se ocupau cu comerțul. Totuşi, lixae pot fi considerați mai degrabă negustori cu un statut special, aceştia fiind agreaţi de armată. De altfel, o serie de inscripții funerare militează pentru ataşarea formală a acestora la trupele romane: prima, descoperită la Colonia Ulpia Noviomagus în Germania Inferior, îl menționează pe Aurelius Flavii f(ilius) Flavinus, lixa ann(orum) XVIII, activând pe lângă Legio X Gemina în care servise şi tatăl său Flavius. La Carnuntum (Pannonia Superior), în secolul I p.Chr., la începutul domniei lui Claudius, este atestat C(aius) Aemilius, C(ai) f(ilius), Fab(ia) Pata(vio) Lixa an(norum) $X X V^{21}$, un comerciant din canabele legiunii XV Apollinaris ${ }^{22}$. O altă inscripție, din Siria îl menționează pe M(arcus) Titius Lixa, de pe lângă cohors III Thracum Syriaca ${ }^{23}$, editorul considerând că Lixa ar fi un cognomen, dar ulterior îşi va corecta lectura inițială, prezentând o nouă variantă: $M$ (arcus) Titius lixa coh(ortis) III Thracum Syriac(ae), vixit annos $X L^{24}$. În sfârşit, la Oescus apare L(ucius) Freius, L(ucii) l(ibertus), F(austus), lixa leg(ionis) $V$ $(\text { Macedonicae })^{25}$, care poate fi plasat în această zonă în perioada în care această legiune şi-a avut garnizoana aici, cel mai probabil după anul 71 p. Chr.

Exceptând sursele epigrafice, aprovizionarea militarilor cu alimente de la aceste categorii de comercianți este susţinută de numeroase surse narative. De exemplu, în contextul revoltei lui Iulius Civilis din 69 p. Chr, comandantul castrului de la Vetera ia măsura dărâmării clădirilor comercianților care se dezvoltaseră într-o veritabilă aşezare ${ }^{26}$.

Perceperea lixae-lor ca elemente care perverteau moravurile soldaţilor romani se regăseşte şi la alți autori care afirmă că aceştia urmează trupele doar pentru a câştiga bani, însă nu fac parte din armată (extra ordinem sunt militiae) ${ }^{27}$ şi nu țin cont nici de tribun, nici de general: nu încearcă decât să câşstige prin tot felul de mijloace bune sau rele. Aceştia corup soldații pentru că nu au arme, nu se bucură de încredere şi nu au curaj să atace inamicul ${ }^{28}$. De altfel, adjectivul semilixa desemna soldații răzvrătiți. Din cauza acestei conduite nu erau admişi în tabăă, ci în cel mai bun caz, li se permitea să se instaleze în apropiere de porta decumana în partea opusă frontului, iar în cel mai rău caz chiar li se interzicea să urmeze armata: ne lixae sequerentur exercitum ${ }^{29}$.

\section{I.2. Statut}

În ceea ce priveşte statutul lor, deşi apar de multe ori în corelație cu calones, care erau sclavi ai soldaților, lixae erau fără îndoială oameni de condiție liberă. În sprijinul acestei conjecturi militează faptul că un lixa putea avea calitate de martor în Senat, privilegiu al oamenilor liberi $^{30}$. Mai mult, Ammianus Marcellinus face o distincție clară între lixae şi sclavi ${ }^{31}$, iar în Codex Theodosianus lixae apar în mod expres ca homines condicionis ingenua ${ }^{32}$. De

\footnotetext{
${ }^{20}$ Sallustius, Iug., 44, 5.

${ }^{21}$ CIL III 11259.

${ }^{22}$ Ivanov 1990, 134

${ }^{23}$ AÉ 1980887 = AÉ 19901012 = Speidel 1980, 146-148.

${ }^{24}$ Speidel 1981, 272.

${ }^{25}$ AÉ 1990862.

${ }^{26}$ Tacitus, Hist., 4, 22, 1.

${ }^{27}$ Festus, De verborum segnificatu, 103.

${ }^{28}$ Cf. Suidas s.v. $\lambda \varepsilon 1 \xi \alpha$.

${ }^{29}$ Sallustius, Iug., 45, 2.

${ }^{30}$ Titus Livius, Ab Urbe Cond., 31, 49,11.

${ }^{31}$ Ammianus Marcellinus, 28, 2, 13.

${ }^{32}$ Cod. Theod., 7, 1, 10.
} 
asemenea, în 367 p. Chr. Valentinian I emite un edict către Iovinus, magister equitum, în care se stipula că foarte mulți soldați iau cu ei adesea oameni născuți liberi, pretinzând că sunt rude sau lixae $^{33}$. Această uzanță nu pare circumscrisă doar secolului al IV-lea p. Chr., o situație similară fiind semnalată mult mai timpuriu, într-o inscripție funerară de la Ulpia Noviomagus de la sfârşitul secolului I p. Chr. menționându-se trei bărbaţi care aparent au murit în aceeaşi bătălie: doi frați, soldaţi ai legiunii X Gemina şi fiul de 18 ani al fratelui mai mare, care era lixa ${ }^{34}$.

Interferența civililor cu armata nu se rezumă doar la cazul romanilor, ci poate fi întâlnită şi în cadrul altor armate: Frontinus îi menționează în cadrul armatei ateniene ${ }^{35}$, Curtius Rufus se referă de mai multe ori la lixae calonesque când descrie armata persană ${ }^{36}$, Iustinus înregistrează prezența bucătarilor şi a brutarilor printre lixae care urmau armata lui Antiochus al III-lea în campania împotriva parților ${ }^{37}$, iar Orosius îi aminteşte la rândul său chiar în armata parților ${ }^{38}$. Totuşi este imposibil de stabilit dacă aceşti autori descriu un corp având caracteristici similare cu lixae sau adaptează aceste realități la cunoştințele lor. Faptul că aceştia reprezentau o realitate mai degrabă romană poate fi susținut de lipsa unui sinonim în limba greacă, Suidas folosind transliteraţia grecească a termenului: $\lambda \varepsilon \tilde{i} \xi \alpha l$.

\section{Calones}

În sursele narative antice, în corelație cu prima categorie, prezentată anterior, se întâlneşte şi o alta, calones, diferenţiată însă fundamental de lixae prin statutul social, aceştia fiind sclavi ai soldaților, deținuți cu titlu privat sau aparţinând statului ${ }^{39}$. De altfel, condiția servilă rezultă în mod explicit dintr-un pasaj al lui Tacitus care menționează că numărul lor era mai mare decât cel al sclavilor lixae--lor ${ }^{40}$.

\section{II.1. Funcții}

\section{II.1.1. Funcții logistice}

Şi în cazul lor, ca şi pentru lixae, s-a urmărit decelarea funcției pe baza etimologiei termenului care îi desemnează şi care ar fi provenit de la grecesul $\kappa \alpha \lambda \alpha^{41}$. Aceşti calones au fost aşadar puşi în legătură cu strângerea lemnului necesar pentru foc sau pentru realizarea valului din jurul taberei. Elocventă este mărturia lui Titus Livius care îi prezintă cărând lemne pentru val $^{42}$. La Zela, în 47 a. Chr, Caesar a ordonat sclavilor armatei să care materialele necesare pentru ridicarea fortificației, pentru ca nici un soldat să nu părăsească munca de fortificare ${ }^{43}$. Acelaşi rol este confirmat şi de Frontinus, deşi cu referire la armata macedoneană, care spune că aceştia cărau frânghii şi roți de moară ${ }^{44}$.

La alți autori antici, calones apar ca fiind persoanele care adunau grâul ${ }^{45}$. Într-adevăr Caesar aminteşte o frumentatio întreprinsă de Quintus Cicero în 53 a. Chr la care iau parte şi calones $^{46}$, iar un scoliast al lui Horațiu nota că unii considerau că termenul calo derivă de la

\footnotetext{
${ }^{33}$ Ibidem.

${ }^{34}$ CIL XIII 8732: Aurelius T. f. Gal./ Flavos Gal. mil. leg. X/ gem. ann. XL stip XVIII/ et M. Aurelius T. f./ Gal. Festus Callag./ ann. XXXVIII stip. XVII/ et Aurelius Flavi f./ Flavinus lixa ann./ XVIII hic siti sunt/ S. v. t. 1. H. f. c.

${ }^{35}$ Frontinus, Str., 2.1.6.

${ }^{36}$ Curtius Rufus, Hist. Alex Mag., 8, 4, 13; 3, 3, 25; 6, 8, 23.

${ }^{37}$ Iustinus, Epit., 38, 10, 2.

${ }^{38}$ Orosius, Hist. adv. Pag., 2, 41.

${ }^{39}$ Speidel 1989, 239-247; Roth 1999, 93-101.

${ }^{40}$ Tacitus, Hist., 2, 87, 2.

${ }^{41}$ Festus, s.v. calo.

${ }^{42}$ Titus Livius, Ab Urbe Cond., 23, 16, 8.

${ }^{43}$ Hirtius, B. Alex., 73.

${ }^{44}$ Frontinus, Str., 4,1,6.

${ }^{45}$ Frontinus, Str. 3,2,9; Caesar, B. Gall., 6, 36; Ammianus Marcellinus, 22, 2, 8.

${ }^{46}$ Caesar, B. Gall., 6, 36.
} 
kalendae, prima zi a lunii, când soldații îşi primeau rația de grâu ${ }^{47}$. De asemenea, la Caesar calones mai apar amintiți cu ocazia unor pabulationes în timpul campaniilor contra bellovacilor din 51 a. $\mathrm{Chr}^{48}$.

În timpul campaniei lui Caesar din 49 a. Chr, când romanii se confruntă cu o acută criză de provizii, acesta ia hotărârea de a rechiziţiona vite din satele hispanice şi îi trimite pe calones să le aducă ${ }^{49}$. Totuşi, cel mai frecvent, calones apar asociaţi cu animalele de povară şi implicit cu bagajele armatei. Acelaşi autor ne transmite că un atac asupra proviziilor sale s-a soldat cu moartea unor calones şi a unor animale de povară ${ }^{50}$, iar Titus Livius afirmă că din tabăra lui Valerius de la Suessula lipseau calones, caii şi animalele de povară ${ }^{51}$. Tot în această arie se înscrie şi una din scrisorile de la Vindolanda, în care se menționează că armata romană beneficia de sclavi care îngrijeau animalele ${ }^{52}$.

Cel mai probabil este că aceştia îşi desfăşurau activitatea în toate domeniile logisticii, eliberând soldatul de o serie de sarcini şi oferindu-i astfel o disponibilitate militară mai mare. Funcția minimală a acestor calones era de a păzi bagajele soldaților în timpul luptelor şi al marşului, rol confirmat şi de Vegetius ${ }^{53}$, dar această datorie se dovedea adesea complexă, dacă avem în vedere descrierea manevrelor pe care le-au executat aceștia în timpul bătăliei din vara lui 52 p. Chr., ceea ce dă măsura disciplinei $\operatorname{lor}^{54}$. Paza bagajelor nu reprezenta însă singura atribuție a sclavilor, pentru că aceştia însoțeau soldații la exerciții şi realizau toate lucrurile care reprezentau îndatoririle curente ale unui sclav domestic.

\section{II.1.2. Funcții militare}

Chiar dacă aceste grupuri sunt considerate a fi personal necombatant, totuşi, dictat de necesități, ele puteau avea unele roluri în desfăşurarea propriu-zisă a luptei. Cel mai adesea, aceştia strigau împreună cu soldații pentru a-i înspământa pe inamici ${ }^{55}$.

O altă manevră executată de calones este cea din timpul unei lupte cu samniții, când, la ordinul comandantului, aceştia au tras pe pământ crengi pentru a ridica praful şi a simula astfel un atac al cavaleriei ${ }^{56}$. Într-o manieră asemănătoare ar fi procedat şi Marius, care în timpul luptei de la Aquae Sextiae din anul 102 a.Chr. i-ar fi înarmat pe lixae şi pe calones şi le-ar fi ordonat să încalece pe animale de povară pentru a crea impresia unei cavalerii mai numeroase ${ }^{57}$.

În opera sa autobiografică, Caesar îi prezintă pe calones ca făcând parte de facto din armată. De exemplu, în batălia de la Thapsus, locuitorii care încercau să-şi ajute propria armată au fost respinşi cu pietre şi sulițe de către sclavii lasaţi în tabără - a servitiis puerisque, qui in castris erant, lapidibus pilisque ${ }^{58}$. De altfel, rolul lor combativ este prezentat mult mai explicit la Cassius Dio care afirmă că aceştia au reuşit să salveze tabăra lui Macrinus în 217 p.Chr. de atacul parţilor ${ }^{59}$. Ca un eveniment extraordinar apare şi ajutorul oferit de către lixae la apărarea castrelor de la Vetera şi Bonna în timpul revoltei lui Iulius Civilis în 69 p.Chr. ${ }^{60}$. Mai mult chiar,

\footnotetext{
${ }^{47}$ Porphyrius, ad Hor. Sat., 1, 2, 44.

${ }^{48}$ Caesar, B. Gall., 7, 20; 8, 10.

${ }^{49}$ Caesar, B. Civ., 1, 51.

${ }^{50}$ Caesar, B. Civ., 1, 52.

${ }^{51}$ Titus Livius, Ab Urbe Cond., 7, 37.

${ }^{52}$ Tab. Vindol, II, 180.

${ }^{53}$ Vegetius, Epit., 3, 6, 2.

${ }^{54}$ Caesar, B. Gall., 7, 67, 3.

${ }^{55}$ Frontinus, Str., 2, 4, 8; Titus Livius, Ab Urbe Cond., 23, 16, 8; 40, $28,3$.

${ }^{56}$ Titus Livius, Ab Urbe Cond., 10, 41, 6.

${ }^{57}$ Frontinus, Str., 2, 4, 6.

${ }^{58}$ Hirtius, B. Afr., 85, 1-2.

${ }^{59}$ Cassius Dio, 78, 265.

${ }^{60}$ Tacitus, Hist. 4, 20, 22.
} 
Flavius Iosephus considera că trăind alături de soldați şi asistând la exercițiile lor deveniseră asemănători acestora, fiindu-le însă inferiori în îndemânare şi valoare ${ }^{61}$.

Vegetius afirma că sclavii răniți sau inspăimântați puteau răspândi dezordinea în rândurile armatei şi în consecință romanii au conferit şi sectorului bagajelor armatei o organizare militară, celor mai experimentați dintre calones dându-li-se comanda a până la 200 de animale de povară şi a altor sclavi, precum şi steaguri, pentru a uşura astfel depozitarea bagajelor $^{62}$. Acelaşi autor întrevedea necesitatea ca şi sclavii să fie învățaţi să înoate în eventualitatea traversării unor râuri pe teritoriul inamic ${ }^{63}$.

O altă problemă controversată este dacă aceşti sclavi militari erau sau nu înarmaţi. Sursele prezintă aceste informații antagonic. Motivul pentru care sclavii călăreților apar înarmați este lesne de înțeles. Pe de o parte purtau armele de rezervă ale stăpânului, aceştia fiind adesea

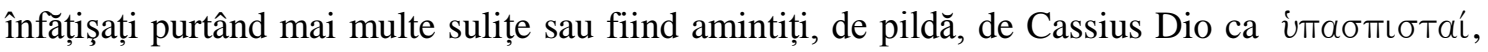
cu sensul de purtători de scuturi, dar, pe de altă parte, echipamentul militar, cu deosebire cel defensiv era necesar pentru propria protecție.

$\mathrm{Cu}$ privire la sclavii infanteriştilor, este foarte probabil ca inițial, în perioada republicană, aceştia să nu fi fost înarmați. În acest sens, mărturie stau pasajele autorilor antici. Astfel, Titus Livius face referire la turba calonum care aruncă cu pietre în cartaginezi la Baecula în 208 a.Chr ${ }^{64}$. Spre sfârşitul secolului al II-lea a.Chr, putem surprinde deja o schimbare. În descrierea campaniei lui Marius împotriva teutonilor, Plutarh aminteşte că în momentul în care sclavii s-au îndreptat spre un râu pentru a se aproviziona cu apă, au luat cu ei şi topoare, săbii şi lăncii ${ }^{65}$. Caesar scrie că în bătălia de la Sambre din 57 a. Chr, văzând panica belgilor, îi atacă pe aceştia deşi erau inermes, termen ce face referire mai probabil la faptul că erau uşor înarmați. Exceptându-i pe calones, unde se poate observa o treptată supunere rigorilor disiplinei militare şi chiar înarmarea lor, mai ales după ce armata romană se permanentizează, se poate observa că şi lixae sau alte categorii de civili sunt utilizaţi ca forță militară în situaţii extreme. Astfel, Calpurnius Piso, în lupta sa cu Germanicus pentru controlul Siriei în anul 19 p. Chr, i-ar fi înarmat pe $l i x a e^{66}$, iar în timpul atacului batavilor asupa Bonnului, în 69 p.Chr, Herrenius Gallus i-a înarmat pe lixae şi pe țărani (pagani), Tacitus caracterizând ambele grupuri ca lipsite de curaj - ignava, dar dând dovadă de îndrăzneală până în momentul în care întâlneau efectiv un pericol $^{67}$.

Sursele greceşti prezintă la rândul lor două categorii distincte de sclavi. Onasander îi împarte în $\psi \iota \lambda o$ ś şi ả $\nu 0 \pi \lambda o r$ - persoane neînarmate. Şi alți autori identifică un grup cu atribuții pur logistice, dar şi un altul mai belicos: $\sigma \kappa \eta \nu o \phi v ́ \lambda a \kappa \in S$, cei ce păzesc corturile militarilor şi

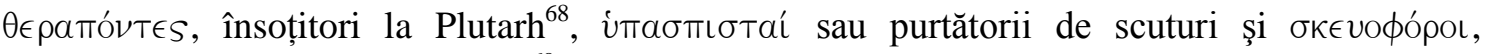
purtătorii de bagaje la Cassius Dio ${ }^{69}$.

Deşi erau considerați personal necombatant, dat fiind faptul că trăiau în proximitatea armatei şi uneori chiar erau considerați o ultimă rezervă a acesteia, atât lixae, cât şi calones puteau să se confrunte cu situaţii care le punea viaţa în pericol, de multe ori acestea dovedinduse chiar fatale. Conform mărturiilor narative, deşi cifrele în mod sigur sunt exagerate, la

\footnotetext{
${ }^{61}$ Flavius Iosephus, B. Iud., 3, 69.

${ }^{62}$ Vegetius, Epit., 3, 6.

${ }^{63}$ Vegetius, Epit., 1, 10.

${ }^{64}$ Titus Livius, Ab Urbe Cond., 27, 18, 12.

${ }^{65}$ Plutarh, Mar., 19, 1.

${ }^{66}$ Tacitus, Ann., 2, 78.

${ }^{67}$ Tacitus, Ann., 4, 20.

${ }^{68}$ Plutarh, Pomp., 72, 3.

${ }^{69}$ Cassius Dio, 79, 26, 6.
} 
începutul războiului cu Mithridate ar fi fost masacrați 80.000 de comercianți romani şi italici ${ }^{70}$. Hirtius menționează cum un elefant rănit se prăbuşeşte şi ucide un lixa din tabăra lui Caesar. De asemenea, Marcus Antonius ar fi pierdut un sfert din soldați, dar şi o treime din sclavii care îi urmau armata $^{71}$. Titus Livius relatează şi el pierderea unui număr mare de calones după ce un grup de traci au atacat bagajele unui coloane militare ${ }^{72}$. Acest lucru se explică prin faptul că în timpul marşului, lixae şi calones se aflau în zona bagajelor, care constituia cea mai vulnerabilă parte a coloanei. De altfel, Ammianus Marcellinus afirmă că împăratul Iulian Apostatul şi-a poziționat bagajele, pe calones şi ceilalți însoțitori neînarmați între două corpuri de armată pentru a nu fi răpiţi, cum se întâmplă adesea ${ }^{73}$.

Viaţa le putea fi primejduită însă şi ca rezultat al propriilor acțiuni, pentru că în dorinţa de a jefui teritoriile pe care le străbăteau se îndepărtau de sub protecția armatei, devenind vulnerabili. De exemplu, Titus Livius nota că locuitorii din Astapa îi capturau pe soldaţii, dar şi pe lixae şi calones care se îndepărtau de armată $\breve{~}^{74}$.

\section{II.3. Efectiv}

În ceea ce priveşte efectivul sclavilor, chiar dacă aprecierile antice pot fi considerate exagerate, numărul lor trebuie să fi fost cu adevărat ridicat, din moment ce erau folosiţi pentru a crea impresia unei armate mai numeroase. Frontinus relatează că în timpul celui de-al doilea război punic, Claudius Marcellus, temându-se că în toiul luptei s-ar putea învedera numărul mic al forțelor sale, a ordonat ca lixae, calones şi cei ce urmau tabăra (sequellae), indiferent de categoria din care făceau parte, să se amestece cu armata ${ }^{75}$. Integrarea lor în rândul soldaților, ca o diversiune, pentru a crea impresia unei armate augumentate, dovedeşte că numărul lor nu era unul neglijabil.

Pentru o perioadă mai veche se poate aminti un fragment al lui Valerius Antias, citat de Titus Livius $^{76}$ şi Orosius ${ }^{77}$, unde se afirmă că la sfârşitul secolului al II-lea a. Chr, într-o luptă cu cimbrii, au fost ucişi 80.000 de soldaţi şi 40.000 de calones şi lixae.

Conform altor mărturii narative, numărul personalului necombatant îl putea chiar depăşi pe cel al soldaților. Astfel, Vitellius ar fi mărşăluit spre Roma însoțit de 60.000 de oameni şi de un număr şi mai mare de sclavi - sexaginta milia armatorum sequebatur, licentia corrupta; calonum numerus amplior $^{78}$, situație similară cu cea de la intrarea în Cremona - Quadraginta armatorum milia inrupere, calonum lixarumque amplior numerus ${ }^{79}$. Fără îndoială, cifrele prezentate în aceste exemple sunt exagerate şi foarte probabil în rândul lor erau incluşi şi sclavii privați, precum şi celelalte categorii de civili care urmau armata. De altfel, Quintilianus realiza o comparaţie extrem de plastică între poezia care avea numeroase epitete şi armata care era însoțită de numeroşi lixae, care îi dublau efectivul, dar nu şi puterea ${ }^{80}$.

Pentru mânarea animalelor de povară şi pentru transportul echipamentului şi al proviziilor, L. Peddie apreciază ca ar fi fost necesar un număr de 1000 de sclavi pe legiune, mai exact un sclav pentru fiecare animal ${ }^{81}$. Această estimare pare însă forțată, întrucât experința

\footnotetext{
${ }^{70}$ Titus Livius, Per., 78; Appian, Mith., 4, 22-9; Plutarh, Sulla, 11; Cassius Dio, 31-35.

${ }^{71}$ Velleius Paterculus, Hist. Rom., 2, 82, 3.

${ }^{72}$ Titus Livius, Ab Urbe Cond., 38, 41, 3.

${ }^{73}$ Ammianus Marcellinus, 24, 1, 4.

${ }^{74}$ Titus Livius, Ab Urbe Cond., 28, 23, 3.

${ }^{75}$ Frontinus, Str., 2, 4, 8.

${ }^{76}$ Titus Livius, Ab Urbe Cond., 67, 8.

${ }^{77}$ Orosius, Hist. adv. Pag., 5, 16, 3.

${ }^{78}$ Tacitus, Hist., 2, 87.

${ }^{79}$ Tacitus, Hist., 3, 33

${ }^{80}$ Quintilianus, Inst., 8, 6, 42.

${ }^{81}$ Peddie 1994, 52.
} 
practică, precum şi studiul comparativ în relație cu armatele moderne care utilizau animalele de povară în aceleaşi scopuri ca şi cea romană dovedeşte că mai multe animale de povară puteau fi mânate de un singur om. Mult mai plauzibil pare un raport de 4:1 între personalul combatant şi cel necombatant, rezultând astfel la nivel teoretic un efectiv al sclavilor de 1200 pentru o legiune de 4800 de oameni - 120 pentru o cohortă, 20 pentru o centurie şi 2 pentru un contubernium $^{82}$. Păstrând proporțiile putem considera că prima cohortă dublă a legiunii imperiale era deservită de 240 de calones.

Deşi, după cum se poate observa, pentru sclavii infanteriştilor nu se poate stabili cu certitudine un număr fix, în schimb pentru cei ai cavaleriştilor se pot opera unele deducții, deoarece probabil fiecare beneficia de serviciile unui sclav. Mărturie în acest sens stau stelele funerare datate în perioada Flaviilor din Germania Inferior, unul dintre registre având întotdeauna figurat un sclav care aduce calul stăpânului său ${ }^{83}$. Astfel, Frontinus afirmă că fiecare cavalerist avea câte un calo, în timp ce infanteriştii aveau fiecare câte zece - equitibus non amplius quam singulos calones habere permisit, peditibus autem denis singulos ${ }^{84}$. Membrii gărzii imperiale vor beneficia de acelaşi tratament şi în secolul al III-lea p. Chr., una dintre stelele lor funerare purtând chiar o inscripție a unuia dintre aceşti sclavi: Et Quarto, lib(erto) eius supervixit dies $X X I^{85}$, un indiciu clar al faptului că acest personaj fusese de condiție servilă. În mod evident, purtătorii de arme care aduceau caii sau urmau un călăreț (reprezentați pe diferite monumente funerare de cavalerişti) sunt sclavi. Totodată, un papir provenind de la Dura-Europos atestă dublarea rațiilor pentru călăreți (dar nu şi pentru infanterişti), ceea ce ar putea însemna că în anul 219 p. Chr., guvernatorul dispusese hrănirea doar a sclavilor călăreților, rația excedentară fiind destinată evident hrănirii acestora ${ }^{86}$.

Exceptându-i pe calones, care erau ataşaţi armatei în mod oficial, se întâlnesc cazuri când în rândurile militarilor îşi fac simțită prezența şi sclavi deținuți cu titlu privat. Astfel, când intră în Tarentum în 213 a. Chr., Gaius Livius era însoțit de sclavii săi ${ }^{87}$. Appian menționează că la asediul ce a vizat Uttica, unul dintre ofițeri era însoțit de un sclav iberic ${ }^{88}$. Plutarh menționează că suita celui de-al doilea Cato, tribunus militum în Macedonia în anul 67 a. Chr cuprindea 15 sclavi, 2 oameni liberi şi 4 amici $^{89}$. În timpul traversării lui Caesar din Sicilia în Africa, unul dintre ofițerii săi, Caius Avienus, a încărcat o întreaga corabie numai cu bagajele şi sclavii săi $i^{0}$. Când Octavian organizează deplasarea dintre Italia şi Grecia, premergătoare luptei de la Actium, acesta limitează numărul sclavilor personali ai ofițeriilor săi ${ }^{91}$, iar Tacitus ne informează că soldații răzvrătiți în 14 p.Chr. torturează sclavii comandantului Iunius Blaesus ${ }^{92}$.

Sursele epigrafice se dovedesc a fi parcimonioase în privința acestui aspect. Unul dintre centurionii legiunii a V-a Macedonica este însoțit în timpul războiului partic de doi sclavi ${ }^{93}$, iar un centurion al legiunii a XVI-a Gallica de la Mogontiacum deține şi el un sclav ${ }^{94}$. Dintr-o scrisoare a unui centurion de la Vindolanda, în care acesta cerea diferite articole de

\footnotetext{
${ }^{82}$ Roth 1999, 354-358.

${ }^{83}$ Galsterer,Galsterer 1975, nr. 246, 247, 253, 255, 256.

${ }^{84}$ Frontinus, Str., 4,1,6; Hyginus, De mun. cast., 5, 30: fiecare legiune avea câte 533 vexilarii pentru impedimenta; von Petrikovitz 1975, 47.

${ }^{85}$ CIL VI 3304.

${ }^{86}$ P. Dura $100=$ CLA VIII 355.

${ }^{87}$ Polybios, Hist., 8, 30, 6 .

${ }^{88}$ Appian, Pun., 5, 30.

${ }^{89}$ Plutarh, Cat. Min., 9, 2.

${ }^{90}$ Hirtius, B. Afr., 54.

${ }^{91}$ Cassius Dio, 50, 11, 6.

${ }^{92}$ Cassius Dio, 57; 4, 2.

${ }^{93}$ Mitford 1988, 167-177, nr. 9; Strobel1988, 39-42.

${ }^{94}$ CIL XIII 11836.
} 
îmbrăcăminte pentru sclavii săi, reiese că respectivul se bucura de serviciile a aproximativ şaseşapte astfel de persoane ${ }^{95}$. Un alt centurion avea nu mai puțin de nouă sclavi ${ }^{96}$. Un subcornicularius tribuni deținea trei vernae ${ }^{97}$, iar un alt sclav este atestat în proprietatea unui aquilifer ${ }^{98}$.

Piatra de mormânt a unui servus deținut de un soldat din trupele de equites singulares Augusti, descoperită la Apamea, în Siria, denotă faptul că sclavii îşi urmau stăpânul în campanie $^{99}$. La fel se pare că este cazul şi cu doi sclavi care îşi găsesc sfârşitul alături de stăpânul lor, un centurion, la Pădurea Teutoburgică ${ }^{100}$.

\section{II.4. Modul de obținere al sclavilor}

Modul de obținere a acestor sclavi de către armată este divers: cumpărare, rechiziționarea (cum procedează Scipio Africanul în 209 a. Chr., care obține astfel 2000 de sclavi ${ }^{101}$ ) sau chiar prin daruri, cum se întâmplă în 129 p. Chr., când cappadocienii trimit sclavi pentru uzul armatei împăratului Hadrian ${ }^{102}$.

Foarte uzuală era probabil însă aducerea lor de acasă. Astfel, un edict din anul 326 p. Chr. permitea celui care aducea doi cai sau un cal şi un sclav să se înroleze direct cu gradul de circitor $^{103}$. În favoarea acestei idei vin şi numeroasele cazuri de sclavi care aveau aceeaşi naționalitate cu stăpânul lor. Astfel, un african împreună cu sclavul său sunt cunoscuți la Cemenelum ${ }^{104}$, un iranian cu sclavul său la Mainz ${ }^{105}$, iar între equites singulares Augusti întâlnim la Roma un Marsacus, un Batavus, un Helvetius, sau un Noricus ${ }^{106}$. De asemenea, Mauricius afirma că de multe ori sclavii militari erau copiii sau alte rude ale soldaților ${ }^{107}$.

$* * *$

Deşi legionarii romani erau deprinşi să îşi care singuri echipamentul şi proviziile pentru trei zile (sarcina), acestea având o greutate considerabilă, motiv pentru care ajung să fie denumiți ironic prin sintagma „măgarii lui Marius”, s-a învederat necesitatea unor persoane specializate în transportul corturilor, a rațiilor suplimentare de hrană, dar şi a echipamentul militar voluminos.

Armata romană nu dispunea de unități de suport logistic independente, formate din necombatanţi şi în consecinţă acest rol îl vor juca sclavii militarilor - calones.

Rolul lor însă nu se rezuma doar la îndatoririle enumerate mai sus, ci activitatea lor incumba nenumărate alte sarcini logistice, eliberând soldatul de muncile inutile şi conferindu-i astfel o diponibilitate mai mare pentru rolul său fundamental - lupta.

Exceptând sclavii, sursele menționează şi o altă categorie de civili - lixae, cu ocupaţii diverse, dar cel mai adesea amintiți în legătură cu vânzarea de alimente. Aceştia se diferențiau de alte categorii de comercianţi prin ataşarea formală la una dintre trupele romane, mărturie în acest sens stând descoperirile epigrafice.

Deşi funcțiile acestor două grupuri puteau fi complementare, fapt ce ar explica şi frecventa lor alăturare în sursele narative (lixae calonesque), diferența fundamentală era reprezentată fără îndoială de statutul social.

\footnotetext{
${ }^{95}$ Tab. Vindol., II, 255.

${ }^{96}$ CIL III 8143 = IMS II 325.

${ }^{97}$ CIL VI 3596.

${ }^{98}$ CIL XIII 8649.

${ }^{99}$ Speidel 1980, 146.

${ }^{100}$ CIL XIII 8648 = ILS 2224.

${ }^{101}$ Polybios, Hist., 10, 17, 9.

${ }^{102}$ K-H. Welwei 1988, 105-106.

${ }^{103}$ Cod. Theod., 7, 22, 2.

${ }^{104}$ CIL V 7895.

${ }^{105}$ Selzer 1988, nr. 91

${ }^{106}$ Speidel 1994, nr. 691, 692, 695, 696, 703.

${ }^{107}$ Mauricius, Strat., 5, 1.
} 
$\mathrm{Nu}$ numai că lixae şi calones ofereau o varietate de bunuri şi servicii soldaţilor, dar puteau fi folosiți şi într-o manieră tactică, cu precădere pentru a înşela adversarul cu privire la efectivul real al trupelor.

\section{BIBLIOGRAFIE}

Barbieri 1964 - G. Barbieri, Lixa, DEAR IV, 1426-1427.

Cagnat 1904 - R. Cagnat, Lixa, DA III, 1279.

Feig Vishnia 2002 - R. Feig Vishnia, The Shadow Army: The Lixae and the Roman Legions, ZPE 139, 265-272.

Galsterer, Galsterer 1975 - B Galsterer, G. Galsterer, Die römischen Steininschriften aus Köln, Köln. Grosse 1926 - R. Grosse, Lixa, Realencyclopädie der Classischen Altertumswissenschaft XIII, col. 929-930. Ivanov 1990 - R. Ivanov, Lixa Legionis V Macedonicae aus Oescus, ZPE 80, 131-136.

Kissel 1995 - Theodor Kissel, Untersuchungen zur Logistik des römischen Heeres in den Provinzen des griechischen Ostens (27 v.Chr. -235 n.Chr.), St. Katharinen.

Mitford 1988 - T. B. Mitford, Further Inscriptions from the Cappadocian Limes, ZPE 71, 167-178.

Neumann 1979 - A. Neumann, Lixa, Der Kleine Pauly, München III, 699.

Peddie 1994 - J. Peddie, The Roman War Machine, Conshohocken.

von Petrikovitz $1975-$ H. von Petrikovitz, Die Innenbauten römischer Legionslager während der Prinzipatszeit, Opladen.

von Petrikovitz 1980 - H. von Petrikovitz, Lixae, Limes 12 Stirling, 1027-1035.

Schlippschuh 1987 - O. Schlippschuh, Die Händler im römischen Kaiserreich in Gallien, Germanien und in den Donauprovinzen Raetien, Noricum und Pannonien, Amsterdam.

Roth 1999 - J. P. Roth, The Logistics of the Roman Army at War, Leiden, Boston, Köln.

Selzer 1988 - W. Selzer, Römische Steindenkmäler. Mainz in römischer Zeit, Maiz.

Speidel 1980 - M. P. Speidel, Lixa of the Third Thracian Cohort in Syria: A New Inscription, ZPE 38, 146-148.

Speidel 1989 - M. P. Speidel, The Soldiers`Servants, Ancient Society 20, 239-247.

Speidel 1994 - M. P. Speidel, Die Denkmäler der Kaiserreiter. Equites singulares Augusti, Köln.

Strobel 1988 - K. Strobel, Ein neues Zeugnis für die Truppengeschichte des Partherkriges Trajans, Epigraphica Anatolica 12, 39-42.

Thoburn 2003 - J. E. Thorburn, Lixae and calones: following the Roman Army, Classical Bulletin Wauconda 79, 47-61.

Welwei 1988 - K-H. Welwei, Unfreie im antiken Kriegsdienst III. Rom, Stuttgart.

Wierschowski 1984 — L. Wierschowski, Heer und Wirtschaft: Das römische Heer der Prinzipatzeit als Wirtschaftsfaktor, Bonn. 